\title{
Challenges Facing High-volume Interlibrary Loan Operations: Baseline Data and Trends in the CIC Consortium
}

\section{Anne K. Beaubien, Jennifer Kuehn, Barbara Smolow, and Suzanne M. Ward}

\begin{abstract}
Interlibrary loan managers of a consortial group of large academic libraries presented a comprehensive report of their collective activities to their library directors to provide a better picture of their libraries' resource- sharing activities, issues, and trends. The report covered three years of data and addressed trends in overall volume, turnaround time, serials-holding data in OCLC, lending audiovisual materials, reasons for unfilled lending requests, and resource-sharing aspects of electronic licensing. The study documents the importance of technical service's role in maintaining accurate OCLC holdings and in facilitating union listing, two activities that have a tremendous impact on ILL effectiveness and efficiency. It also demonstrates that presenting common issues collectively to top administrators resulted in changes that might not have been achieved so easily at single institutions. This paper summarizes the report on consortial resource sharing, lists the report's four recommendations, and reviews the positive changes in the participating libraries' resource-sharing practices six months later.
\end{abstract}

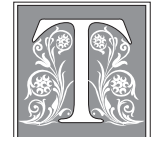

he library directors of the Committee on Institutional Cooperation (CIC) meet periodically at the CIC headquarters in Chicago. ${ }^{1}$ In June 2004, their

agenda included a segment on resource sharing and the authors were invited to form a subgroup of the CIC ILL directors to prepare a report for the meeting. The report's goal was to outline the major

Anne K. Beaubien is Director, Cooperative Access Services and Grants, in the University Library at the University of Michigan; e-mail: beaubien@umich.edu. Jennifer Kuehn is Head, Interlibrary Loan, at Ohio State University Libraries; e-mail: kuehn.1@osu.edu. Barbara Smolow is Head, Interlibrary Loan Department, at Northwestern University Library; e-mail: b-smolow@northwestern.edu. Suzanne M. Ward is Head, Access Services, at Purdue University Libraries; e-mail: ward@purdue.edu. The initial report and this article would not have been possible without the generous cooperation of our CIC ILL colleagues. They worked hard to fit their local internal data into a form that could be used to compare the same elements across all libraries and offered insightful comments at various stages of the report's development. Susan Singleton, director of the CIC's Center for Library Initiatives, compiled some of the data and provided unfailing support and encouragement. Michael Witt, technical information systems analyst at Purdue University Libraries, wrote the ILLiad borrowing turnaround query and assisted colleagues in running it. Suzanne Garrett of the University of Michigan's University Library provided invaluable assistance in providing uniform formatting for the tables in preparation for publication. 
challenges of managing high-volume ILL operations in the current environment of high patron expectations, rising costs, copyright and electronic licensing issues, changing automation choices, emerging formats for scholarly materials, and other factors. The ILL directors viewed this opportunity as a chance not only to inform the library directors, but also to compare our institutions' resource-sharing statistics and practices in a new way.

The CIC library directors are interested in discussing the issues surrounding resource sharing for many reasons. One reason is that the debate concerning ownership versus access has interested the library profession for several decades. It now seems clear that ownership of library materials on the scale enjoyed twenty or thirty years ago is unlikely even at large research institutions, even though access to these materials is more critical than ever and is likely to remain so in the future. The key to meeting patrons' needs for locally unavailable material is the ability to rely on fast, efficient, and generous borrowing partners. Any institution that expects such service should be prepared to provide the same to its partners. Membership in a consortium with reciprocal lending agreements is one important tool that a library can use to draw cost-effectively on the resources of similar institutions while sharing its own.

To introduce the report, the CIC ILL directors proposed a "snapshot view" of the CIC institutions' resource-sharing activities. This view would meet the following three objectives:

- To provide three years of baseline data

- To show comparable statistics across institutions

- To reveal trends over time and among institutions

The authors quickly discovered that, apart from a few basic numbers (such as annual totals reported to the ARL), all our offices collect and report internal statistics very differently. The first challenge was to define the essential data elements; the second was to ask our counterparts across the consortium to compile the data in a uniform manner. ${ }^{2}$

Data were compiled from July 1, 2001 through March 30, 2004. This period is three months short of three full fiscal years; the library directors' meeting in early June 2004 necessitated using estimated figures for the last three months of FY04. The tables show either extrapolated figures for the last three months of this fiscal year or indicate that data were collected only through March 30, 2004.

\section{Total ILL Activity for CIC Libraries, FY02-FY04}

Table 1, the "snapshot view," summarizes the total ILL activity for the CIC libraries, reflecting a total of almost one million borrowing and lending requests filled among CIC institutions during the threeyear period.

All CIC libraries use OCLC for processing ILL requests among CIC libraries. Some also use RLIN and/or Docline for non-CIC transactions; these figures were included in the table to show the total volume of ILL traffic at each institution.

For borrowing, the percentages of requests filled by CIC partners range from 8 (University of Illinois, UrbanaChampaign, FY04) to 74 percent (Northwestern University, FY02). For lending, the percentages for filled requests range from 12 (University of Illinois, UrbanaChampaign, FY02 and FY04) to 50 percent (University of Michigan, FY02). Some CIC libraries select CIC partners as their first choices for filling lending requests; others tend to turn first to local or in-state borrowing partners and then to CIC partners. Libraries with the lower percentages of CIC-to-CIC transactions on this table have particularly strong reciprocal ILL relationships with in-state libraries, principally those with strong academic collections.

For example, in FY04, 45 percent of the University of Iowa's borrowing transactions were with CIC partners. However, only 29 percent of its lending traffic was 
Challenges Facing High-volume Interlibrary Loan Operations 65

\begin{tabular}{|c|c|c|c|c|c|c|c|c|c|c|c|c|c|c|c|c|c|c|}
\hline \multirow{6}{*}{\multicolumn{2}{|c|}{ Z }} & 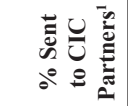 & & ڤें & 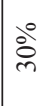 & लें & & 总 & $\stackrel{\circ}{\beth}$ & $\stackrel{\circ}{\circ}$ & \multirow{3}{*}{\multicolumn{2}{|c|}{ 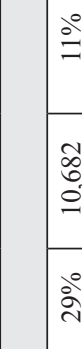 }} & 웅 & \multirow{2}{*}{ 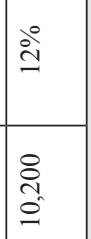 } & \multirow{2}{*}{\multicolumn{2}{|c|}{$\begin{array}{l}2 \\
2 \\
2 \\
2 \\
2\end{array}$}} & \multirow{2}{*}{ 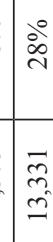 } & \multirow{2}{*}{ 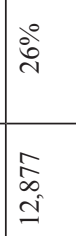 } \\
\hline & & 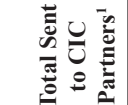 & & $\begin{array}{l}\tilde{N} \\
\hat{O} \\
= \\
=\end{array}$ & $\stackrel{\cong}{=}$ & $\begin{array}{l}n \\
\tilde{b} \\
\mathfrak{y}\end{array}$ & & $\begin{array}{c}\infty \\
\infty \\
\stackrel{5}{c} \\
\end{array}$ & $\mid \begin{array}{l}\hat{n} \\
\hat{m}\end{array}$ & $\begin{array}{l}\infty \\
\infty \\
\infty \\
\tilde{n}\end{array}$ & & & $\stackrel{n}{\stackrel{\sim}{\sim}}=$ & & & & & \\
\hline & & 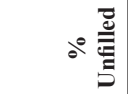 & & $\begin{array}{l}\text { ¿े } \\
\text { in } \\
\text { in }\end{array}$ & ठ̊ㅇㅇ & ì & & $\stackrel{\stackrel{0}{+}}{\stackrel{\gamma}{+}}$ & ळें & ळें & & & $\frac{\partial^{\circ}}{\gamma}$ & $\begin{array}{l}\stackrel{0}{\infty} \\
\infty \\
m\end{array}$ & & dें & ì & \&ें \\
\hline & & 窇总 & & $\begin{array}{l}\tilde{m} \\
\stackrel{2}{n} \\
\text { ñ }\end{array}$ & $\begin{array}{l}\tilde{n} \\
n \\
n \\
n\end{array}$ & $\begin{array}{l}n \\
\hat{n} \\
b \\
f\end{array}$ & & $\begin{array}{l}\hat{o} \\
\infty \\
\infty \\
\infty\end{array}$ & 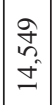 & $\begin{array}{l}0 \\
0 \\
m \\
n\end{array}$ & & $\begin{array}{l}8 \\
0 \\
0 \\
\text { ले }\end{array}$ & 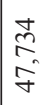 & $\begin{array}{l}\text { ते } \\
\infty \\
\text { in }\end{array}$ & & $\begin{array}{l}\infty \\
0 \\
\text { ले }\end{array}$ & 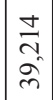 & $\begin{array}{l}\hat{n} \\
\hat{\sigma} \\
\gamma\end{array}$ \\
\hline & & & & $\begin{array}{l}\Xi \\
\Xi \\
\infty \\
\infty\end{array}$ & $\begin{array}{l}\vec{b} \\
\infty \\
0 \\
i\end{array}$ & $\begin{array}{l}\hat{D} \\
m \\
n \\
m\end{array}$ & & 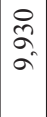 & $\left|\begin{array}{l}n \\
\tilde{n} \\
\sim \\
\tilde{n}\end{array}\right|$ & 卓 & & 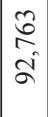 & $\begin{array}{l}2 \\
2 \\
2 \\
8 \\
8\end{array}$ & $\begin{array}{l}\vec{\infty} \\
\infty \\
\infty\end{array}$ & & 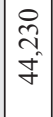 & $\mid \begin{array}{l}0 \\
0 \\
0 \\
f \\
f\end{array}$ & 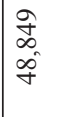 \\
\hline & & 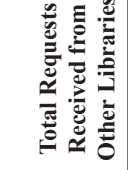 & & $\begin{array}{l}8 \\
8 \\
\text { à }\end{array}$ & 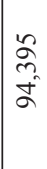 & $\begin{array}{l}\text { के } \\
\infty \\
\infty\end{array}$ & & $\begin{array}{l}\hat{m} \\
\infty \\
\infty\end{array}$ & $\mid \begin{array}{c}0 \\
0 \\
0 \\
0 \\
m \\
m\end{array}$ & $\begin{array}{l}\text { cै } \\
\text { iv } \\
\text { mे }\end{array}$ & & $\begin{array}{l}\tilde{I} \\
\tilde{I} \\
\tilde{\Xi}\end{array}$ & $\begin{array}{l}\stackrel{m}{m} \\
\stackrel{m}{ \pm} \\
=\end{array}$ & $\begin{array}{l}0 \\
0 \\
0 \\
6 \\
0 \\
0 \\
0\end{array}$ & & 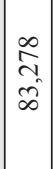 & 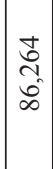 & $\begin{array}{l}8 \\
8 \\
\infty \\
8\end{array}$ \\
\hline 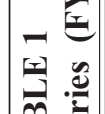 & & 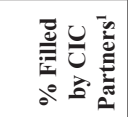 & & 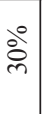 & 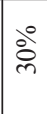 & $\stackrel{\stackrel{\circ}{े}}{m}$ & & $\stackrel{\circ}{\stackrel{2}{I}}$ & $\stackrel{0}{\circ}$ & $\stackrel{\circ}{\stackrel{0}{ }}$ & & $\grave{0}$ & @े & $\check{\alpha}^{\circ}$ & & 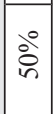 & $\begin{array}{c}\circ \\
\stackrel{\circ}{+} \\
\stackrel{+}{\circ}\end{array}$ & iें \\
\hline 를 & & 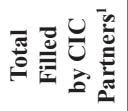 & & 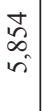 & 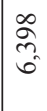 & $\begin{array}{l}\infty \\
\sigma \\
r \\
\sim\end{array}$ & & $\begin{array}{c}n \\
\tilde{r} \\
m \\
m\end{array}$ & $\begin{array}{c}n \\
\tilde{n} \\
n\end{array} \mid$ & $\frac{\tilde{\partial}}{\tilde{m}}$ & & 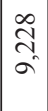 & $\frac{\grave{2}}{i}$ & $\begin{array}{l}\widetilde{\hat{~}} \\
\text { b. }\end{array}$ & & $\begin{array}{l}\stackrel{一}{\Xi} \\
\stackrel{n}{2}\end{array}$ & $\mid \begin{array}{l}\tilde{O} \\
\delta \\
\pm \\
\pm\end{array}$ & $\begin{array}{l}0 \\
\stackrel{0}{0} \\
\sim \\
1\end{array}$ \\
\hline 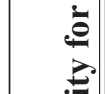 & ט & 决总 & & ذి & i̊ & $\stackrel{0}{\infty}$ & & ఏ̊ర & in & $\stackrel{\infty}{\infty}$ & & ذి & bे & $\stackrel{\circ}{=}$ & & $\begin{array}{l}\stackrel{0}{a} \\
\stackrel{a}{2}\end{array}$ & $\stackrel{0}{0}$ & $\stackrel{\stackrel{0}{\lambda}}{\stackrel{0}{0}}$ \\
\hline 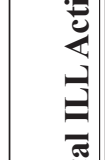 & 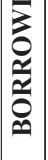 & 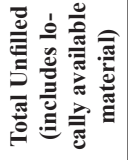 & & $\begin{array}{l}\vec{F} \\
\infty \\
m\end{array}$ & 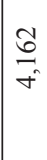 & $\begin{array}{l}8 \\
\text { o } \\
\text { in }\end{array}$ & & $\begin{array}{c}\vec{F} \\
m \\
m\end{array}$ & $\left|\begin{array}{l}\hat{2} \\
\hat{a} \\
\hat{i}\end{array}\right|$ & $\begin{array}{l}0 \\
\text { m } \\
i\end{array}$ & & $\begin{array}{l}0 \\
\vec{F} \\
\therefore\end{array}$ & 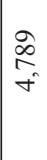 & $\underset{\infty}{\stackrel{i}{N}}$ & & $\begin{array}{l}2 \\
\stackrel{0}{0}\end{array}$ & $\begin{array}{l}\vec{F} \\
+ \\
0 \\
0\end{array}$ & 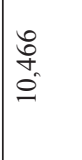 \\
\hline & & 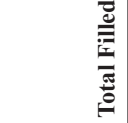 & & $\begin{array}{l}\tilde{m} \\
2 \\
2\end{array}$ & $\mid \begin{array}{l}0 \\
0 \\
\infty \\
0 \\
8\end{array}$ & $\begin{array}{l}\hat{o} \\
\text { ñ } \\
\text { î }\end{array}$ & & $\begin{array}{l}\tilde{\sigma} \\
\tilde{\sigma} \\
\tilde{\sigma}\end{array}$ & 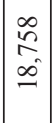 & 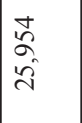 & & $\begin{array}{l}\vec{\lambda} \\
2 \\
\infty\end{array}$ & $\begin{array}{l}z \\
n \\
i \\
i\end{array}$ & 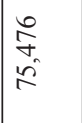 & & 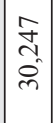 & $\mid \begin{array}{l}\infty \\
\infty \\
\infty \\
\infty \\
\infty\end{array}$ & $\begin{array}{l}\vec{G} \\
\stackrel{i}{a}\end{array}$ \\
\hline & & 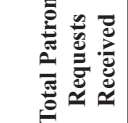 & & $\begin{array}{l}\tilde{n} \\
\hat{a} \\
\hat{d}\end{array}$ & $\begin{array}{l}a \\
0 \\
2 \\
i\end{array}$ & 命 & & $\begin{array}{l}\stackrel{ \pm}{N} \\
\underset{\sim}{2}\end{array}$ & $\mid \begin{array}{c}m \\
\stackrel{n}{i} \\
i\end{array}$ & $\begin{array}{l}+ \\
\infty \\
i \\
\infty \\
i\end{array}$ & & 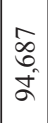 & 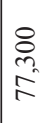 & $\begin{array}{l}\tilde{O} \\
\tilde{1} \\
\dot{\infty}\end{array}$ & & 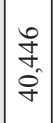 & $\begin{array}{l}\hat{y} \\
\text { aे } \\
\text { m}\end{array}$ & $\mid \begin{array}{l}\hat{0} \\
\infty \\
\infty \\
n\end{array}$ \\
\hline & & & 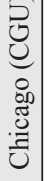 & ¿̂े & 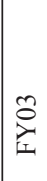 & 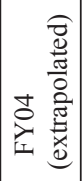 & $\begin{array}{l}\underset{3}{\Xi} \\
0 \\
\vdots\end{array}$ & 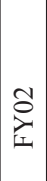 & $\begin{array}{l}m \\
\hat{x}\end{array}$ & 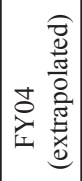 & 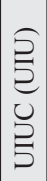 & ¿ิ & 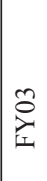 & 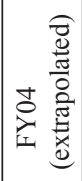 & 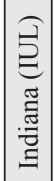 & 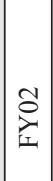 & ڤ & 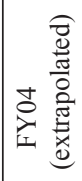 \\
\hline
\end{tabular}




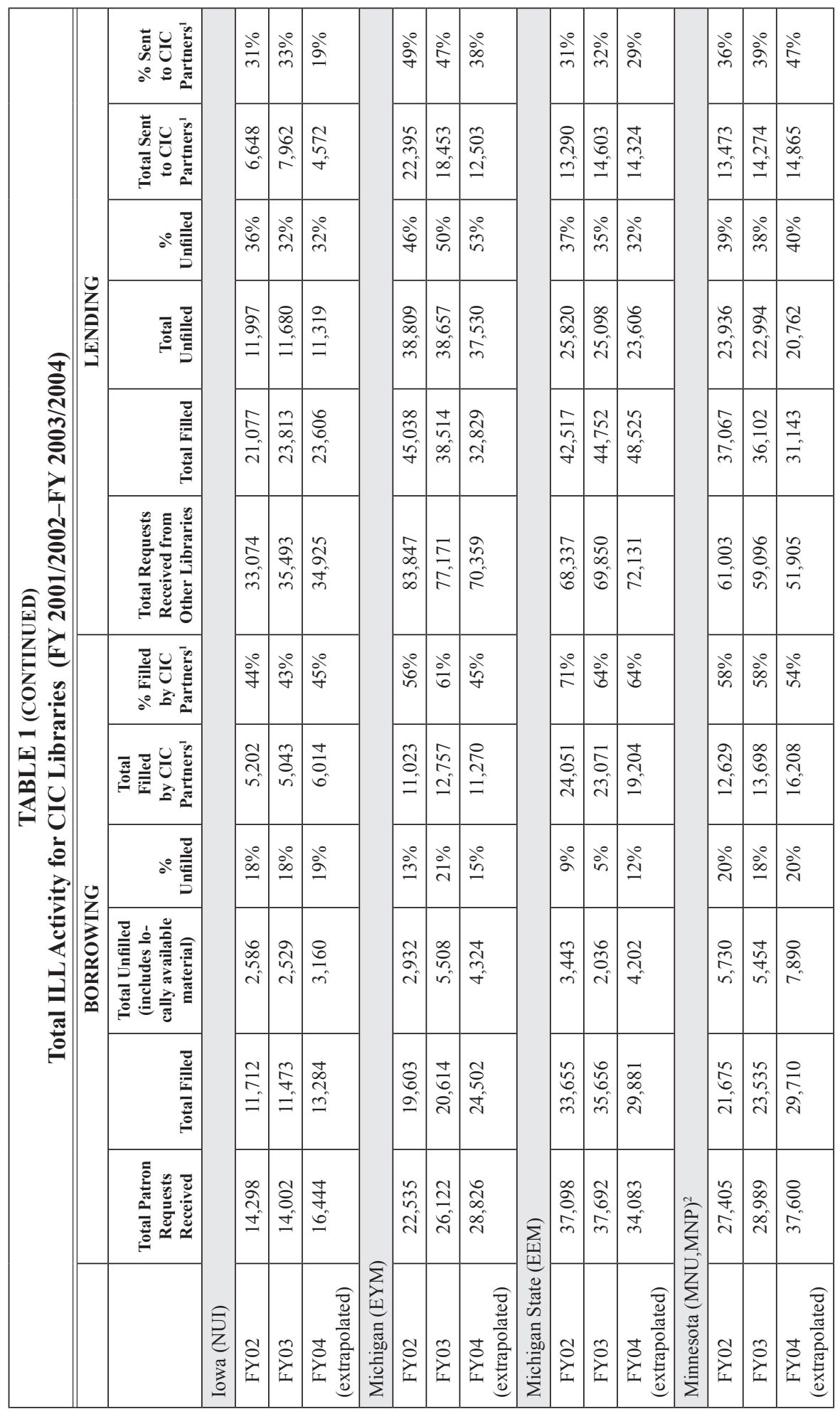


Challenges Facing High-volume Interlibrary Loan Operations 67

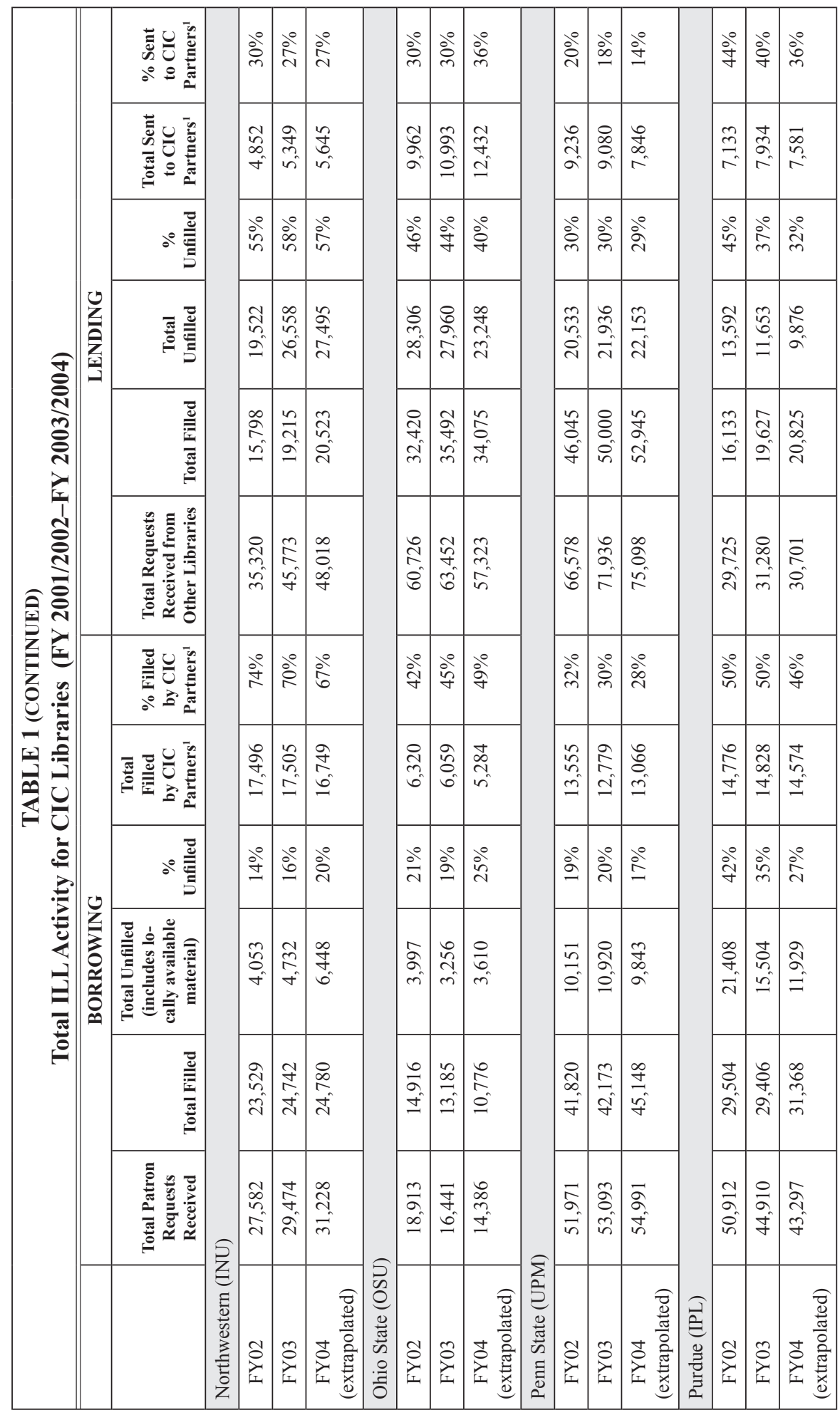




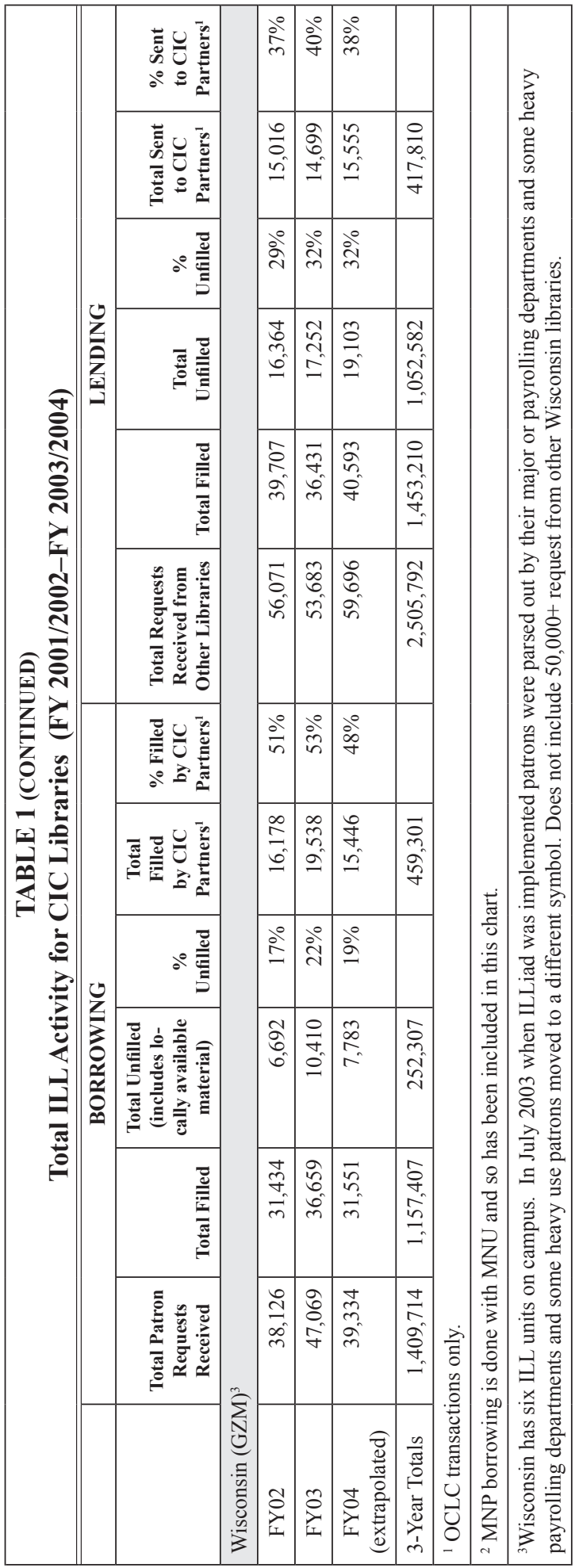

with CIC libraries, suggesting that the University of Iowa was a major resourcesharing source for other libraries in Iowa. For the entire FY02-FY04 time frame, the University of Illinois, Urbana-Champaign, borrowed between 8 and 10 percent of its filled ILL transactions from CIC partners and lent between 12 and 17 percent to CIC partners. The University of Illinois, Urbana-Champaign, has the largest library collection of any publicly supported university in the United States; this low percentage suggests that the CIC libraries have been successful in their conscious efforts to borrow from the University of Illinois, Urbana-Champaign, as a last resort to avoid overloading this partner. In general, table 1 shows that in terms of percentages of the total volume, CIC libraries lend more heavily to other libraries (probably those in their own states) than they do to each other.

\section{Borrowing Requests}

The total number of borrowing requests increased during these three years in all but five libraries, with the most dramatic increase being at the University of Minnesota $(27 \%)$. The percent of requests unfilled (including requests for locally available items) ranged from 5 to 42 percent. Table 1 counts both the total number of requests received from patrons and the total filled through ILL activity. The CIC ILL directors feel that the total number of requests received is an accurate 
reflection of the activity, effort, and costs associated with processing patrons' requests.

This study defined "unfilled" requests as those items that were available locally or that could not be obtained through ILL. ARL statistics only ask for the total number of patron requests processed through ILL channels, and of those, the ones that are successfully filled versus those that were unfilled. ILL practitioners have long chafed at these definitions. In many ILL operations, patrons ask for a significant number of items that are available locally. In many institutions, defining "unfilled" as only those requests that fail in the ILL process overlooks a third or more of the total effort required to handle patron requests. (The discussion of table 7 later in this article more fully explores the concept of unfilled requests.)

\section{Lending Requests}

The total number of lending requests also increased in all but five libraries (a different set of five than those discussed in the section on borrowing requests). The largest increases were at the University of Illinois, Chicago (45\%), and Northwestern University (27\%). The percentage of lending requests that were unfilled ranged between 29 and 61 percent. Unfilled rates for lending requests are naturally higher than for unfilled borrowing requests for both reasons that the lender cannot control (for example, item checked out or not found on shelf) and reasons the lender can control (for example, providing accurate local serials-holdings information on OCLC). (Unfilled lending requests are discussed in depth in the section on table 6.)

\section{Returnables versus Nonreturnables}

ILL statistics gathering often differentiates between nonreturnables (photocopies) and returnables (loans). The costs associated with handling these two types of transactions are different. ${ }^{3}$ Table 2 shows the CIC libraries' ILL activity divided between these two categories. Looking at the table as a whole, no overall trends or patterns emerged, although individual institutions may note significant changes.

\section{Borrowing Turnaround Time}

Transactions are completed more rapidly between CIC libraries than between a CIC library and a non-CIC library. Overall turnaround time for borrowing requests is an important measure of a library's success in filling patron requests quickly. It also is one of the most difficult elements to measure. Major discussion points revolve around when the clock starts and stops and whether time should be measured in calendar days or business days. For this report, turnaround time was measured in calendar days from the time that ILL staff sent a request to the first potential supplier to the time that the requested item was received in the borrowing ILL office. ${ }^{4}$ Table 3 reports each institution's average turnaround time for both borrowing and lending between July 2003 and March 2004.

The average turnaround time for filling requests for returnables (loans) among CIC libraries ranged from 6.5 to 13.7 calendar days. Requests for nonreturnables (generally articles delivered electronically via Ariel) were filled in an average range of 4.6 to 7.0 calendar days among CIC partners. Comparable turnaround ranges for receiving items from non-CIC libraries were 7.6 to 17.6 days for returnables and 4.1 to 9.6 days for nonreturnables.

Many CIC ILL operations give priority handling to requests from other CIC libraries. The CIC libraries commit to delivering articles electronically whenever licensing permits; the group also uses an express courier service for the transfer of nonreturnables among institutions. The authors believe that these practices result in the faster turnaround time among consortial partners.

\section{Serials Holding Data in OCLC}

Overall turnaround time for patrons is reduced by first determining which libraries hold the requested volume/year of a serial and then sending requests 


\begin{tabular}{|c|c|c|c|c|}
\hline \multicolumn{5}{|c|}{$\begin{array}{c}\text { TABLE } 2 \\
\text { Three-Year Comparison of } \\
\text { Photocopies versus Returnables on OCLC } \\
\text { FY 2001/2002 - FY 2003/2004 }\end{array}$} \\
\hline & \multicolumn{2}{|c|}{ BORROWING } & \multicolumn{2}{|c|}{ LENDING } \\
\hline & $\begin{array}{c}\text { Photocopies } \\
\text { Received }\end{array}$ & $\begin{array}{c}\text { Returnables } \\
\text { Received }\end{array}$ & $\begin{array}{c}\text { Photocopy } \\
\text { Requests Filled }\end{array}$ & $\begin{array}{c}\text { Returnables } \\
\text { Filled }\end{array}$ \\
\hline \multicolumn{5}{|l|}{ Chicago (CGU) } \\
\hline FY02 & 3,880 & 9,262 & 6,902 & 17,274 \\
\hline FY03 & 3,841 & 10,848 & 5,832 & 18,722 \\
\hline FY04 (extrapolated) & 3,669 & 5,849 & 7,988 & 21,008 \\
\hline \multicolumn{5}{|l|}{ UIC (IAY) } \\
\hline FY02 & 4,094 & 2,108 & 1,380 & 8,200 \\
\hline FY03 & 3,764 & 2,621 & 1,642 & 8,585 \\
\hline FY04 (extrapolated) & 3,799 & 1,991 & 1,943 & 6,050 \\
\hline \multicolumn{5}{|l|}{ UIUC (UIU) } \\
\hline FY02 & 10,261 & 10,360 & 17,047 & 14,951 \\
\hline FY03 & 8,835 & 12,835 & 17,643 & 17,716 \\
\hline FY04 (extrapolated) & 8,343 & 12,501 & 16,653 & 16,367 \\
\hline \multicolumn{5}{|l|}{ Indiana (IUL) } \\
\hline FY02 & 14,302 & 15,259 & 18,589 & 23,369 \\
\hline FY03 & 11,708 & 16,497 & 18,685 & 25,363 \\
\hline FY04 (extrapolated) & 11,038 & 14,167 & 18,377 & 22,231 \\
\hline \multicolumn{5}{|l|}{ Iowa (NUI) } \\
\hline FY02 & 4,799 & 6,691 & 8,425 & 9,651 \\
\hline FY03 & 4,407 & 6,764 & 11,177 & 9,471 \\
\hline FY04 (extrapolated) & 5,689 & 8,848 & 13,581 & 9,286 \\
\hline \multicolumn{5}{|l|}{ Michigan (EYM) } \\
\hline FY02 & 7,508 & 9,819 & 23,655 & 14,899 \\
\hline FY03 & 8,189 & 11,848 & 20,837 & 14,963 \\
\hline FY04 (extrapolated) & 10,780 & 13,722 & 15,181 & 13,110 \\
\hline \multicolumn{5}{|l|}{ Michigan State (EEM) } \\
\hline FY02 & 24,300 & 7,633 & 18,841 & 11,665 \\
\hline FY03 & 23,570 & 8,240 & 19,924 & 13,574 \\
\hline FY04 (extrapolated) & 21,195 & 6,920 & 19,763 & 14,263 \\
\hline \multicolumn{5}{|l|}{ Minnesota (MNP,MNU) } \\
\hline FY02 & 7,062 & 12,867 & 19,007 & 9,174 \\
\hline FY03 & 7,574 & 13,406 & 18,164 & 9,249 \\
\hline FY04 (extrapolated) & 9,524 & 19,503 & 17,461 & 10,061 \\
\hline
\end{tabular}




\begin{tabular}{|c|c|c|c|c|}
\hline \multicolumn{5}{|c|}{$\begin{array}{c}\text { TABLE } 2 \text { (CONTINUED) } \\
\text { Three-Year Comparison of } \\
\text { Photocopies versus Returnables on OCLC } \\
\text { FY 2001/2002 - FY 2003/2004 }\end{array}$} \\
\hline & \multicolumn{2}{|c|}{ BORROWING } & \multicolumn{2}{|c|}{ LENDING } \\
\hline & $\begin{array}{l}\text { Photocopies } \\
\text { Received }\end{array}$ & $\begin{array}{c}\text { Returnables } \\
\text { Received }\end{array}$ & $\begin{array}{c}\text { Photocopy } \\
\text { Requests Filled }\end{array}$ & $\begin{array}{c}\text { Returnables } \\
\text { Filled }\end{array}$ \\
\hline \multicolumn{5}{|l|}{ Northwestern (INU) } \\
\hline FY02 & 14,048 & 10,057 & 4,415 & 10,567 \\
\hline FY03 & 12,441 & 12,286 & 6,968 & 11,444 \\
\hline FY04 (extrapolated) & 10,868 & 12,216 & 9,975 & 10,340 \\
\hline \multicolumn{5}{|l|}{ Ohio State (OSU) } \\
\hline FY02 & 8,205 & 5,689 & 18,994 & 11,461 \\
\hline FY03 & 7,615 & 4,693 & 22,229 & 11,588 \\
\hline FY04 (extrapolated) & 7,192 & 4,420 & 25,813 & 11,792 \\
\hline \multicolumn{5}{|l|}{ Penn State (UPM) } \\
\hline FY02 & 21,844 & 13,523 & 24,530 & 10,104 \\
\hline FY03 & 20,543 & 14,028 & 22,818 & 9,679 \\
\hline FY04 (extrapolated) & 20,866 & 17,789 & 23,816 & 9,202 \\
\hline \multicolumn{5}{|l|}{ Purdue (IPL) } \\
\hline FY02 & 19,519 & 8,776 & 11,722 & 4,700 \\
\hline FY03 & 19,044 & 8,682 & 12,172 & 5,354 \\
\hline FY04 (extrapolated) & 18,938 & 9,433 & 11,636 & 4,767 \\
\hline \multicolumn{5}{|l|}{ Wisconsin (GZM) } \\
\hline FY02 & 8,994 & 22,031 & 23,646 & 16,060 \\
\hline FY03 & 11,202 & 25,455 & 20,553 & 15,878 \\
\hline FY04 (extrapolated) & 10,137 & 16,829 & 20,458 & 17,615 \\
\hline
\end{tabular}

only to libraries that have indicated they own the specific volume/year. OCLC's WorldCat is the bibliographic database that ILL offices use to identify libraries that own material. WorldCat provides local data records (LDRs) to show specific information about serial holdings at an institution. Detailed LDRs allow borrowing units to target the libraries that hold the requested volume/number/year of a serial. Lenders also benefit because they then receive only requests for volumes held in their collections, reducing lending workload searching by no longer having to say no to requests for material they do not hold.
Table 4 shows the percentage of each CIC institution's serials for which LDRs have been created and the fill rate for ILL serial requests. There may be a correlation between a low percentage of LDRs and a low lending fill rate. These relationships merit further study.

Ohio State University's (OSU's) experience illustrates the benefits of adding LDRs to OCLC to lending photocopy fill rate. In 1996, OSU's fill rate for lending photocopies was 46 percent; more than half the requests received could not be filled. ILL staff began creating LDRs for specific frequently requested serials; by 2001, the fill rate improved to 58 percent. 
In 2002, OSU arranged with OCLC to batch-load almost 49,000 more LDRs; as of 2004 , the fill rate for copy requests had increased to 65 percent. Two other CIC libraries, the University of Illinois, Urbana-Champaign, and the University of Wisconsin, also have used OCLC's batch Local Data Record Updating Service (LDRUS) to create LDRs.

OCLC also conducted a study of the relationship between LDR data and ILL fill rates. When libraries entered LDR data for their top-requested serial titles, their fill rates increased by a range of 3 to 33 percent. The fill rate increased in direct proportion to the number and percentage of the serials collection for which LDRs were entered. In most cases, there also was a decrease in overall ILL requests because libraries no longer received requests for materials they did not hold..$^{5,6}$

Access to WorldCat and these data is widely available to our patrons as well. Since December 2002, serials holdings data have displayed in WorldCat. Serials holdings are now seen by the public users

\section{TABLE 3}

Borrowing Turnaround Statistics (in calendar days) July 2003-March 2004

\begin{tabular}{|c|c|c|c|c|c|c|}
\hline & \multicolumn{3}{|c|}{ Between CIC Flagship Libraries } & \multicolumn{3}{|c|}{ Other Libraries } \\
\hline $\begin{array}{l}\text { CIC Flagship } \\
\text { Libraries }\end{array}$ & Returnables & $\begin{array}{l}\text { Non- } \\
\text { returnables }\end{array}$ & $\begin{array}{c}\text { Average } \\
\text { CIC }\end{array}$ & Returnables & $\begin{array}{c}\text { Non- } \\
\text { returnables }\end{array}$ & $\begin{array}{l}\text { Average } \\
\text { Other }\end{array}$ \\
\hline $\begin{array}{l}\text { Chicago } \\
\text { (CGU) }\end{array}$ & $\mathrm{n} / \mathrm{a}$ & $\mathrm{n} / \mathrm{a}$ & $\mathrm{n} / \mathrm{a}$ & $\mathrm{n} / \mathrm{a}$ & $\mathrm{n} / \mathrm{a}$ & $\mathrm{n} / \mathrm{a}$ \\
\hline UIC (IAY) & 6.9 & 7.0 & 7.0 & 11.1 & 8.5 & 9.8 \\
\hline UIUC (UIU) & 13.7 & 6.7 & 10.2 & 17.6 & 8.9 & 13.2 \\
\hline Indiana (IUL) & 7.4 & 6.9 & 7.2 & 8.0 & 9.6 & 8.8 \\
\hline Iowa (NUI) & $\mathrm{n} / \mathrm{a}$ & $\mathrm{n} / \mathrm{a}$ & $\mathrm{n} / \mathrm{a}$ & $\mathrm{n} / \mathrm{a}$ & $\mathrm{n} / \mathrm{a}$ & $\mathrm{n} / \mathrm{a}$ \\
\hline $\begin{array}{l}\text { Michigan } \\
\text { (EYM) }\end{array}$ & 7.1 & 5.8 & 6.5 & 13.2 & 5.8 & 9.5 \\
\hline $\begin{array}{l}\text { Michigan State } \\
(\mathrm{EEM})\end{array}$ & 7.2 & 4.5 & 5.9 & 10.3 & 9.5 & 9.9 \\
\hline $\begin{array}{l}\text { Minnesota } \\
\text { (MNU,MNP) }\end{array}$ & $\mathrm{n} / \mathrm{a}$ & $\mathrm{n} / \mathrm{a}$ & $\mathrm{n} / \mathrm{a}$ & 8.2 & 5.2 & 6.7 \\
\hline $\begin{array}{l}\text { Northwestern } \\
\text { (INU) }\end{array}$ & 7.1 & 5.3 & 6.2 & 12.0 & 8.6 & 10.3 \\
\hline $\begin{array}{l}\text { Ohio State } \\
\text { (OSU)* }\end{array}$ & $\mathrm{n} / \mathrm{a}$ & $\mathrm{n} / \mathrm{a}$ & $\mathrm{n} / \mathrm{a}$ & $\mathrm{n} / \mathrm{a}$ & $\mathrm{n} / \mathrm{a}$ & $\mathrm{n} / \mathrm{a}$ \\
\hline $\begin{array}{l}\text { Penn State } \\
\text { (UPM) }\end{array}$ & 9.7 & 6.5 & 8.0 & 10.8 & 5.2 & 8.0 \\
\hline Purdue (IPL) & 7.1 & 4.6 & 5.9 & 7.6 & 4.1 & 5.9 \\
\hline $\begin{array}{l}\text { Wisconsin } \\
(\mathrm{GZM})^{* *}\end{array}$ & 10.6 & 5.8 & 8.2 & 12.9 & 5.4 & 9.2 \\
\hline
\end{tabular}

Requests taking over 60 days to fill have not been included in the numbers.

* OSU changed ILL software midyear and the data were incompatible between systems.

** The figures are a composite of the six ILL shops at UW-Madison. They were unable to extract figures for flagship GZM. 


\begin{tabular}{|c|c|c|c|c|}
\hline \multicolumn{5}{|c|}{$\begin{array}{c}\text { TABLE } 4 \\
\text { LDRs (serial holdings data) in OCLC } \\
\text { July 2003-March } 2004 \\
\end{array}$} \\
\hline & $\begin{array}{l}\text { Bibliographic } \\
\text { Records for } \\
\text { Serials }\end{array}$ & $\begin{array}{c}\text { Serial } \\
\text { Bibliographic } \\
\text { Records with } \\
\text { LDRs }\end{array}$ & $\begin{array}{l}\text { \% of Serial } \\
\text { Bibliographic } \\
\text { Records with } \\
\text { LDRs }\end{array}$ & $\begin{array}{c}\text { Lending Fill } \\
\text { Rate for ILL } \\
\text { Serial Requests }\end{array}$ \\
\hline Chicago (CGU) & 133,898 & 2,189 & $1 \%$ & $37 \%$ \\
\hline UIC (IAY) & 27,850 & 0 & $0 \%$ & $\mathrm{n} / \mathrm{a}$ \\
\hline UIUC (UIU) & 202,511 & 69,359 & $34 \%$ & $42 \%$ \\
\hline Indiana (IUL) & 115,855 & 33,542 & $28 \%$ & $\mathrm{n} / \mathrm{a}$ \\
\hline Iowa (NUI) & 45,365 & 5,247 & $11 \%$ & $67 \%$ \\
\hline $\begin{array}{l}\text { Michigan } \\
\text { (EYM) }\end{array}$ & 136,619 & 21,606 & $15 \%$ & $45 \%$ \\
\hline $\begin{array}{l}\text { Michigan State } \\
(\text { EEM) }\end{array}$ & 110,156 & 100,716 & $91 \%$ & $\mathrm{n} / \mathrm{a}$ \\
\hline $\begin{array}{l}\text { Minnesota } \\
\text { (MNU,MNP) }\end{array}$ & 113,453 & 80,365 & $70 \%$ & $62 \%$ \\
\hline $\begin{array}{l}\text { Northwestern } \\
\text { (INU)* }\end{array}$ & 65,422 & 3,283 & $5 \%$ & $\mathrm{n} / \mathrm{a}$ \\
\hline $\begin{array}{l}\text { Ohio State } \\
\text { (OSU) }\end{array}$ & 127,956 & 49,514 & $38 \%$ & $65 \%$ \\
\hline $\begin{array}{l}\text { Penn State } \\
(\mathrm{UPM})\end{array}$ & 68,660 & 40,119 & $58 \%$ & $66 \%$ \\
\hline Purdue (IPL) & 69,163 & 1,453 & $2 \%$ & $57 \%$ \\
\hline $\begin{array}{l}\text { Wisconsin } \\
\text { (GZM) }\end{array}$ & 138,204 & 113,987 & $82 \%$ & $67 \%$ \\
\hline \multicolumn{5}{|c|}{$\begin{array}{l}\text { LDR data were taken from the OCLC Union List database, and the serial bibliographic } \\
\text { records were taken from the WorldCat database and are current as of March } 2004 \text {. }\end{array}$} \\
\hline * INU has signi & cant additional se & ls for which the & symbol is not lis & ed in WorldCat. \\
\hline
\end{tabular}

of the database as well as by ILL and serials cataloging staff. Open WorldCat provides patrons with a new way of moving from that database to the local catalog.

\section{Borrowing Requests for Audiovisual Material}

The CIC ILL directors agree that patron requests for audiovisual (AV) material are increasing, although there is little hard data because the ILL management programs, such as ILLiad or Clio, group AV loans together with all loans. The increase in patron interest in AV titles may be attributed to a combination of factors, such as instructors using more recordings in the classroom, film studies classes, and students who learn better by listening to or watching material than by reading. Table 5 provides three-year overviews for the increase in $\mathrm{AV}$ requests at the University of Iowa and Northwestern University, the only two institutions that were able to extract retrospective data for $\mathrm{AV}$ requests. As a result of this study, most CIC ILL offices have begun tracking $\mathrm{AV}$ requests in their ILL management programs to provide better data for future analysis.

Historical ILL practice has been that a library should not request types of mate- 


\begin{tabular}{|c|c|c|c|c|c|}
\hline \multicolumn{6}{|c|}{$\begin{array}{c}\text { TABLE } 5 \\
\text { ILL Borrowing Requests for Video/DVD }\end{array}$} \\
\hline & $\begin{array}{l}\text { \# of Titles } \\
\text { Requested }\end{array}$ & $\begin{array}{l}\text { \# of } \\
\text { Requests } \\
\text { Placed }\end{array}$ & $\begin{array}{l}\text { \# of } \\
\text { Requests } \\
\text { Filled }\end{array}$ & $\begin{array}{l}\text { \% of } \\
\text { Requests } \\
\text { Filled }\end{array}$ & $\begin{array}{l}\text { Average \# } \\
\text { of Libraries } \\
\text { Tried }\end{array}$ \\
\hline \multicolumn{6}{|c|}{ Iowa (NUI) } \\
\hline FY 2002 & 42 & 65 & 31 & $47 \%$ & 5.1 \\
\hline FY 2003 & 86 & 108 & 53 & $49 \%$ & 4.2 \\
\hline FY 2004 & 113 & 179 & 86 & $48 \%$ & 5.4 \\
\hline \multicolumn{6}{|c|}{ Northwestern (INU) } \\
\hline FY 2001 & 38 & 52 & 23 & $44 \%$ & 6.0 \\
\hline FY 2002 & 180 & 269 & 67 & $24 \%$ & 7.5 \\
\hline FY 2003 & 178 & 312 & 71 & $22 \%$ & 9.0 \\
\hline \multicolumn{6}{|c|}{$\begin{array}{l}\text { Some titles are difficult to obtain and require more than one OCLC request ( } 5 \text { potential } \\
\text { lenders per OCLC request) before they are filled. }\end{array}$} \\
\hline \multicolumn{6}{|c|}{$\begin{array}{l}\text { Several CIC libraries observe that if you do not lend videos, it is harder to find libraries } \\
\text { that will lend to you. Iowa lends videos and Northwestern did not at the time of the study. } \\
\text { This could explain the differences in the success rates. }\end{array}$} \\
\hline
\end{tabular}

rial from other libraries if it is not itself willing to lend that material type. Because members of one of our major resourcesharing partners, the other CIC libraries, did not generally lend AV material at the time of the study, CIC ILL staff spent more time trying to locate potential suppliers to fill patrons' AV requests than they spent on requests for other material types. Instead of being able to fill these requests by the second or third potential supplier (as is typical for most other requests), ILL staff often have to send the request to nine or more potential suppliers before either receiving the item (often from a library to whom they would not have lent their AV if asked) or giving up.?

The authors believe that the reluctance to lend AV material may date back to the days when these items represented new technologies, when they were comparatively fragile, when rapid door-to-door delivery service was not available, and when AV material was both relatively more expensive and harder to replace than books. Today, the CIC ILL directors question whether conservative AV "noloan" policies are still appropriate. The loss or damage rate should not be any higher than it is for books or microfilm, and that rate is remarkably low given the tens of thousands of items the CIC libraries ship each year. ALA's Guidelines for the Interlibrary Loan of Audiovisual Formats state as the basic principle: "Audiovisual materials should be lent to other libraries and agencies as freely as possible and in a manner that insures that they are protected from loss and damage." ${ }^{\prime 8}$

Although the ILL directors realize that, as with books, AV items on reserve, on hold, or part of expensive reference sets may not be available for loan, the report to the library directors suggested that this is a good opportunity to review local AV loan policies and to propose lifting most restrictions. Perhaps these materials initially could be lent only to CIC partners and then the results of these changes could be analyzed.

\section{Reasons for No}

Table 6 shows the top three reasons at each institution for unfilled ILL lending requests. In all libraries but one, over 22 percent of requests were unfilled because 


\begin{tabular}{|l|c|c|c|c|c|c|}
\hline \multicolumn{7}{|c|}{ TABLE 6 } \\
July 2003-March 2004
\end{tabular}

the potential lending library lacked the volume needed. Michigan State University has only 17 percent of its lending requests unfilled due to a lacking volume and has created LDRs for 91 percent of its serial records, giving this institution the best number in both categories. The other major reasons for no were that the material was in use (in circulation to the library's own patrons); was noncirculating (reference, course reserves, or special collections/archives); or was not on the shelf.

\section{Service Trends in ARL Libraries, 1991-2003}

The CIC is not alone in facing growing numbers of requests from its own patrons as well as from other libraries. The ARL statistics for 1991-2003 show an increase in member libraries' interlibrary borrowing of 113 percent over those years. Appendix 2 compares the changes in ILL activity to other service trends in ARL libraries. For example, total library staff in ARL libraries only increased by two percent over the same period whereas total student enrollment increased 16 percent. It is important to bear in mind that the ARL statistics count completed ILL transactions only. ILL offices in the CIC libraries and elsewhere also have been handling a growing number of patron requests for material held locally. 


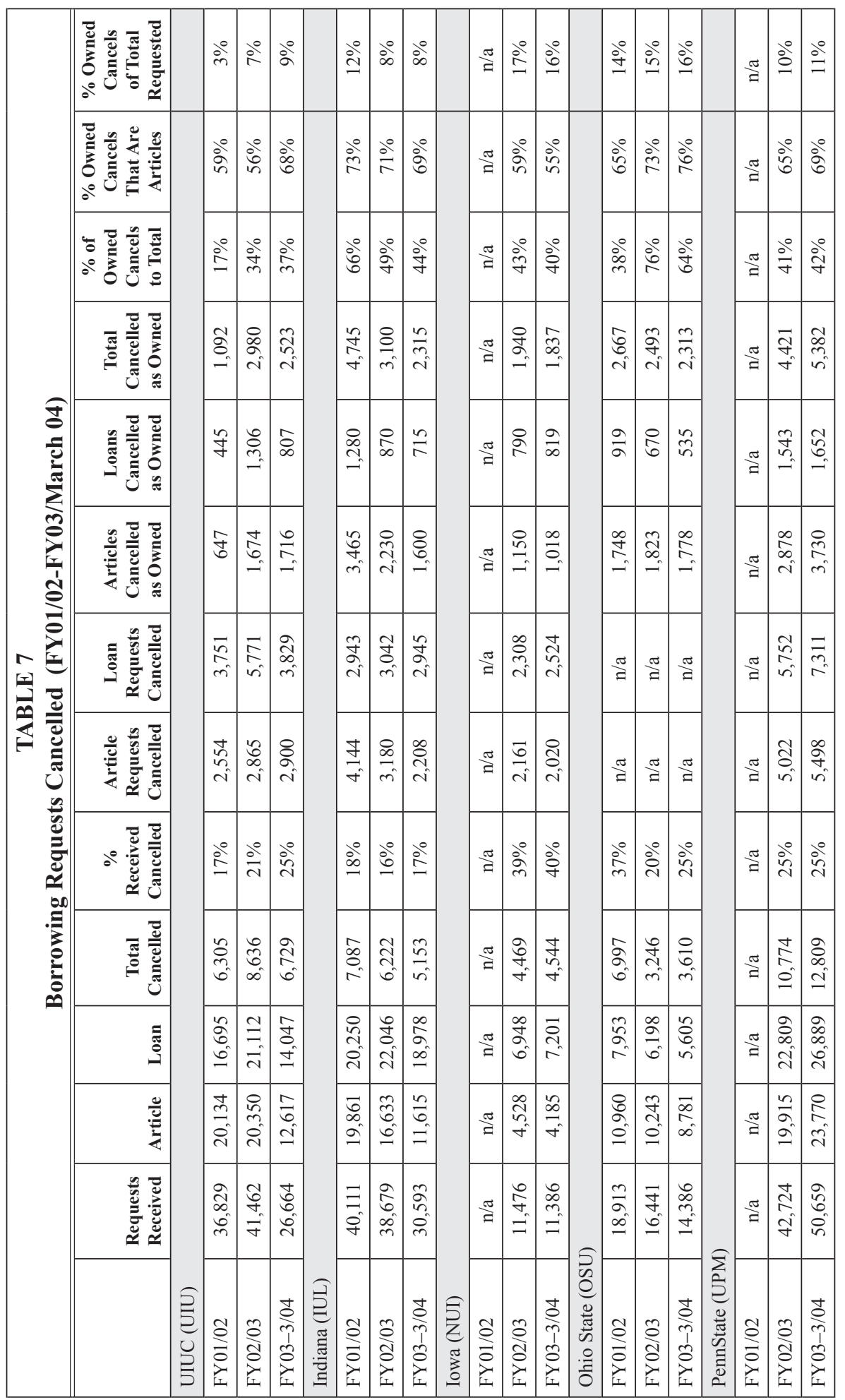




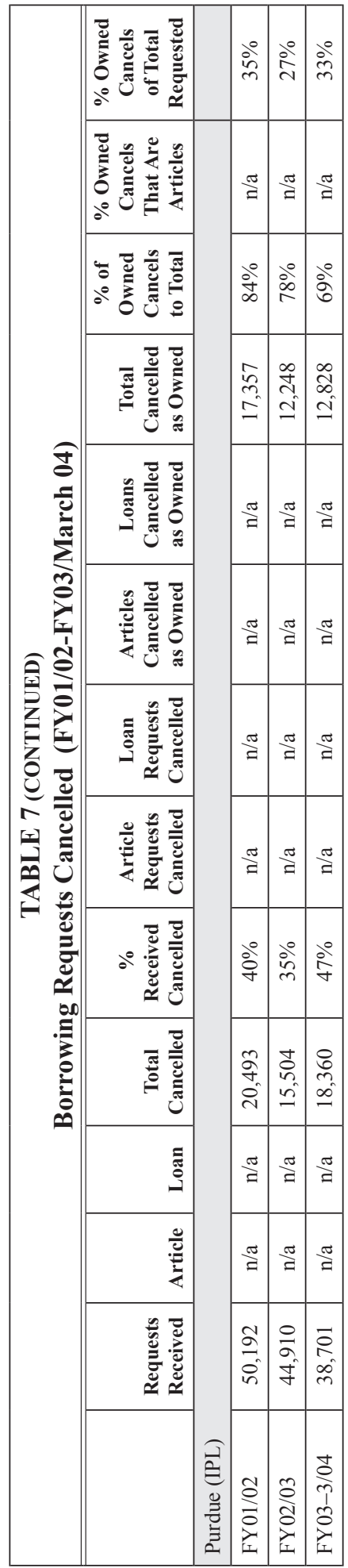

\section{Borrowing Requests for Locally Available Material}

Many users on CIC campuses place borrowing requests that their local ILL offices immediately cancel because the material is available locally. Despite ARL's interest in filled ILL transactions only, many ILL practitioners include requests for locally available material in internal statistics. It is difficult to count a transaction as "unfilled" when, in fact, the ILL staff has connected the patron with the requested material. At research libraries, normal ILL work flow includes thousands of these "cancellations" each year, a considerable effort in terms of decreasing patron wait time and allocating staff time. Significant cost savings are realized by not ordering through ILL material that may be a few clicks away on patrons' desktops or available in their own library's stacks.

Nineteen percent of borrowing requests at all CIC libraries in FY04 were unfilled and represent the median percentage. (See table 1.) For most libraries surveyed, at least 25 percent of all borrowing requests were cancelled because of local availability (the range was 8 to $33 \%$ in FY04). Six CIC libraries supplied data from the last three years on the total number of borrowing requests received, the total number of cancels, and a subtotal of cancels made because the titles were locally available. Table 7 shows that locally held items accounted for 37 to 69 percent of the total cancellations in FY04. Although a review of each institution's individual data reveals few clear trends, when viewed as a whole, these high percentages reflect both a significant expenditure of time and a high degree of expertise on the part of ILL staff.

However, there is a clear pattern that article requests rather than book loan requests make up the majority of orders for locally held materials. It seems that as the number of electronic journals and methods of remote access proliferate, patrons are less able to identify all the resources an institution holds. Patrons who search their local online catalog may 
not also think to check their local e-journal database or, even if they do, may not know the correct title for the abbreviation in their citation. Even patrons who diligently check the catalog may miss a book if their citation refers to a series title (for example, Methods in Enzymology; Annals of the New York Academy of Science; Proceedings of SPIE), but the library catalogs each title in the series separately (for example, Laser Capture Microscopy and Microdissection; Techniques in Bioinformatics and Medical Informatics; or Micromachining Technology for Micro-Optics and Nano-Optics II). These reasons, coupled with easy 24/7 electronic requesting, may mean that ILL offices now receive requests that once would have been mediated at a reference desk. Table 7 confirms that serial titles are more difficult to identify and locate; users often turn to ILL assuming that titles are not held.

Another trend not specifically reflected in the tables is that of ILL staff finding Internet sites for a small, but increasing, number of ILL requests such as: journal articles, conference papers, technical reports, government reports (international, federal, state, and local), working papers, facsimiles of works too old to be protected by copyright laws, association publications, newsletters, dissertations and theses; and more. Instead of having to wait several days for an item, patrons now sometimes are directed to PDF files within a few hours of placing their request. Thus, ILL staff have moved beyond their traditional sphere of citation verification and document ordering. Their skills now include a more sophisticated degree of reference work and patron instruction in bibliographic sources.

\section{Electronic Products Licensing and Resource Sharing}

Although much of the material requested by ILL patrons in academic libraries is covered by fair use, contract law "trumps" the fair-use provisions of the copyright law. Therefore, it is vital that licensing agreements for electronic products address resource-sharing issues.
When these licenses permit resource sharing, they often contain requirements that articles must be printed or that they may not be transmitted electronically (for example, via Ariel or Odyssey). Turnaround time then increases significantly as the lending and borrowing libraries spend additional time printing, shipping, and distributing a paper copy instead of an electronic one.

The CIC model statement for electronic licenses is a good example of suggested license language rather than acceptance of the providers' standard restrictions. ${ }^{9}$ The ability to fill document requests from electronic products in virtually the same way as from paper products is critical in (1) allowing everyone to serve as good resource-sharing partners, (2) ensuring that electronic products can be used by one's own campus's distance education learners and remotely located faculty, and (3) maintaining resource-sharing access to titles when paper subscriptions are dropped or withdrawn in favor of electronic ones.

About half the CIC libraries also maintain a fee-based information service catering to customers without access to the library materials they need for business or personal uses; e-journal license provisions that clarify access and use for both ILL and the fee-based services are critical. At the moment, many electronic titles are supplemented by paper subscriptions, but as these are dropped (or never acquired), fee-based services find themselves increasingly unable to supply customers with articles from on-campus sources.

\section{Cataloging Practice Affects ILL}

WorldCat serves to identify which institutions hold specific titles because the promise of Z39.50 multicatalog searching has not been realized. Accurate, complete, institutional data in the OCLC system are critical to support rapid, cost-effective resource sharing and the full utilization of our partners' collections.

For books, but also increasingly for other formats (such as audiovisual or 
microfilm where full cataloging may not always have been possible), seeing ownership information in OCLC allows ILL staff to send requests to libraries that hold the material. Maintaining this accurate information includes removal of an institution's symbol from the OCLC record when material has been lost as well as adding holdings for the full collection. This maintenance speeds the process of supplying patrons with their material, saves lending staff the time of handling requests for material they cannot supply, and reduces the costs of requesting items from libraries that no longer own material. Although "not owned" was not among the top three lending reasons for no at any CIC institution, it is largely a preventable reason, unlike "in use" or "not on shelf." Purdue University recently removed its symbol from 4,000 OCLC records for items that had long been missing from the collection; several other CIC libraries are now following this example to update their local catalogs and to facilitate resource sharing.

For serials, choosing a lender that holds the specific volume requested improves turnaround time and reduces costs. Institutions that enter and maintain LDRs on OCLC are spared work responding to requests to lend material they do not hold, their resource-sharing partners enjoy faster turnaround time, and their staff can use more time filling requests rather than saying no to them.

Because so many institutions have faced serials cancellation projects, updating LDRs on OCLC to close holdings when a library no longer subscribes saves lending staff time and helps borrowing staff to obtain requested materials more quickly. Although our libraries borrow and lend heavily among their CIC partners, all libraries benefit from this effort. In addition, creating and maintaining these serial-holdings records positions a library to take advantage of future resource-sharing systems and networks that read and route citations at the volume and issue level.

\section{The Report's Recommendations}

The report illustrated that although institutional environments differ in ways that affect resource sharing, each library works toward similar goals. Gathering and analyzing the data highlighted the challenges that ILL offices face and suggested areas for further comparison and research.

The CIC ILL directors asked the library directors to encourage all CIC institutions to target areas where service improvements can aid resource sharing:

- Revising policies so that more AV material can be lent, such as videos, compact discs, and DVDs

- Removing the institution's symbol on OCLC for material no longer in the collection

- Creating and maintaining serialsholdings information (LDRs) on OCLC

- Negotiating e-content licenses to allow the best possible resource-sharing provisions

\section{Changes Resulting from the Report}

Tangible results six months (November 2004) after the report was issued include the following:

- Several libraries are adding more LDRs to OCLC. This activity often involves cooperative work between the library's ILL, technical services, and information technology departments.

- Several libraries are conducting catalog "cleanup" projects and removing their OCLC symbol for material no longer in their collections.

- About half the libraries will now lend at least some of their AV titles. Inspired by the report, a group at the University of Minnesota is now looking more broadly at the issue of instructional media by reviewing current policies and practices for collecting, making accessible, and preserving this material. At Pennsylvania State University, librarians are now examining the current wide variety of $\mathrm{AV}$ loan periods based on library location; they hope to establish a uniform AV loan period. Indiana University increased the AV loan period 
from fourteen to thirty days, the same as for book loans. In revising its policy about AV lending via ILL, Northwestern University also is considering allowing local patrons to check out videos; the collection is currently noncirculating.

- Most CIC ILL offices now tag AV requests in their ILL management systems so that future statistics can be gathered and analyzed.

- The University of Minnesota increased the number of pages it will copy from fifty to seventy-five.

Patricia McCandless, assistant director for public services at the Ohio State University Libraries, summed up an administrator's reaction to the report by writing:

The report confirmed the mutual benefit of union listing journals, and we are committed to continuing that project. By talking collectively about the benefits of resource sharing and recognizing that our protective instincts may not be in the best interests of our patrons, our collection managers agreed to be more generous in lending videos to both the CIC and OhioLINK. ${ }^{10}$

\section{Summary}

The CIC ILL directors welcomed the chance to present to our libraries' top administrators a picture of the challenges and opportunities in consortial resource sharing. Preparing the report for the library directors accomplished many things.

First, it helped the CIC ILL directors identify the major issues that affect every- one's ability to be effective and responsive resource-sharing partners. Next, it helped focus on the issues that were the most important to convey to the library directors. The authors stated each challenge, showed compelling consortia-wide facts and figures, and recommended the most effective actions to solve or ameliorate those issues. Presenting common issues collectively to top administrators carried more weight than did individual efforts at our home institutions.

The ability to provide "apples to apples" data covering several years across all institutions was a major accomplishment. Not only could the authors look at figures for their own institutions in ways that perhaps had not been analyzed before, but they also could benchmark local data against those of their peers. Each library director could see how his or her own institution ranked within the consortium on various resource-sharing measures. These baseline data also can be used for comparisons in any future studies. For instance, if a follow-up study were conducted in three to five years, it could examine the impact of the ILL policy revisions.

Finally, only six months after the library directors read and discussed the report at their meeting, the ILL directors see significant, positive changes in most institutions on one or more of the four major action items. Several libraries now circulate selected AV material, are adding more LDRs to OCLC, and are conducting catalog cleanup projects. These changes result in better access to each other's collections to meet patron needs for locally unavailable research material.

\section{Notes}

1. The CIC is a consortium of major midwestern research universities, composed of the members of the Big 10 athletic conference and the University of Chicago, stretching from Iowa to Pennsylvania. (See appendix 1.) It coordinates many cooperative ventures among its members, including the CIC Center for Library Initiatives (CLI). The CLI serves the thirteen research libraries of the CIC and supports library-related collaboration ranging from archives to digital collection development, including reference services and e-journal subscriptions (www.cic.uiuc.edu).

Among the CLI's activities is the facilitation of an active group of the CIC's ILL directors. (See appendix 3.) This group communicates eight to ten times a year via conference calls and in 


\section{Challenges Facing High-volume Interlibrary Loan Operations 81}

person at the ALA's midwinter and annual meetings. Our institutions have enjoyed a long history of no-charge reciprocal interlibrary borrowing and lending. Since 1998, the CIC has used a courier delivery service (Lanter) to move returnable materials among our libraries, separated at the widest point by 775 miles, usually within two days. Although all CIC libraries also participate in other consortial groups, notably in-state initiatives, we all regard our CIC sister institutions as major resource-sharing partners.

2. After much discussion, the authors decided to count the flagship campus libraries only, not the regional or branch campuses or the separately administered libraries. This decision facilitated the "apples to apples" comparisons the authors had hoped to make. CIC library directors generally administer only the flagship library systems, not the regional and/or specialized libraries, and the full CIC reciprocity agreements extend to the flagship library systems only. A question might arise about the University of Illinois, Urbana-Champaign, and the University of Illinois, Chicago, campuses, but one is not a branch of the other. Instead, the University of Illinois is the only CIC institution with two ARL libraries. The only exception was for the University of Minnesota; when the report was written, its St. Paul campus library had a separate OCLC code and filled a significant number of borrowing transactions for the other campuses. Because the subject areas covered by the St. Paul campus library were included under all the other libraries' flagship OCLC codes, the authors wanted to show the full picture for the University of Minnesota. Since the report was published, the materials in this library have been transferred to Minnesota's flagship OCLC code.

3. Mary E. Jackson, Assessing ILL/DD Services: New Cost-Effective Alternatives (Washington, D.C.: ARL, 2004). The study results found that in 2002 the average ILL transaction cost for participating ARL libraries was $\$ 26.78$ ( $\$ 17.50$ spent by the borrower and $\$ 9.28$ spent by the lender). This publication mentions two CIC libraries, the University of Minnesota and the University of Illinois at Chicago Health Sciences, as high-performing lending operations.

4. Table 3 reports the CIC borrowing turnaround statistics in calendar days between July 2003 and March 2004. Northwestern University and the University of Illinois, Chicago, use Clio as their ILL management system and were able to use that software's system provided report to obtain these figures. The rest of the CIC libraries use ILLiad. IT staff at the Purdue University Libraries wrote a custom query that all CIC libraries using ILLiad ran against their data. Most CIC libraries had moved to ILLiad during the year or two before July 2003, so this table captured only nine months of data. Obtaining and then merging turnaround data from the old system (Clio) and the new one (ILLiad) would not only have been tricky and time-consuming, but also might have introduced elements of inaccuracy or inconsistency.

5. Cathy Kellum, "A Little SOUL Increases ILL Fill Rates," OCLC Newsletter (Nov./Dec. 2000): 33.

6. Anne Donohue, "ILL Fulfillment Study Focuses on Improving Fill Rates," OCLC Newsletter (Nov./Dec. 2000): 34-35.

7. An unpublished study at the University of Michigan showed that 95 percent of all borrowing requests are filled within the first three libraries listed in the OCLC lender string, 1988.

8 Available online at http://www.ala.org/ala/vrt/pubguidelines/guidelinesinterlibrary.

9. Available online at http://www.cic.uiuc.edu/programs/CLIConsortialAgreementProgram/ archive/BestPractice/StandardizedAgreementLanguageDec02.pdf.

10. E-mail communication to Susan Singleton, October1, 2004. 


\begin{tabular}{|c|c|c|c|c|c|c|}
\hline \multicolumn{7}{|c|}{$\begin{array}{c}\text { APPENDIX 1 } \\
\text { CIC Institutions, } 2004\end{array}$} \\
\hline Institution (OCLC Code) & & & & $\begin{array}{l}\text { Volumes } \\
\text { in Library }\end{array}$ & $\begin{array}{c}\text { FTE } \\
\text { Library } \\
\text { Staff* }\end{array}$ & $\begin{array}{l}\text { FTE Student } \\
\text { Enrollment** }\end{array}$ \\
\hline Chicago (CGU) & $\mathrm{b}$ & $\mathrm{L}$ & M & $6,977,186$ & 313 & 10,852 \\
\hline $\begin{array}{l}\text { University of Illinois Chicago } \\
\text { (IAY) }\end{array}$ & & & M & $2,198,873$ & 242 & 21,124 \\
\hline $\begin{array}{l}\text { University of Illinois, } \\
\text { Champaign, Urbana (UIU) }\end{array}$ & & $\mathrm{L}$ & & $10,015,321$ & 531 & 36,356 \\
\hline Indiana (IUL) & G & $\mathrm{L}$ & & $6,647,355$ & 449 & 33,852 \\
\hline Iowa (NUI) & & $\mathrm{L}$ & M & $4,380,734$ & 295 & 23,590 \\
\hline University of Michigan (EYM) & & $\mathrm{L}$ & $\mathrm{M}$ & $7,800,389$ & 621 & 35,623 \\
\hline Michigan State (EEM) & & & & $4,582,004$ & 277 & 37,961 \\
\hline Minnesota (MNP, MNU) & $\mathrm{b}$ & $\mathrm{L}$ & M & $6,200,669$ & 405 & 33,880 \\
\hline Northwestern (INU) & $\mathrm{B}$ & $\mathrm{L}$ & M & $4,315,314$ & 343 & 14,065 \\
\hline Ohio State (OSU) & $\mathrm{B}$ & & M & $5,674,784$ & 405 & 41,940 \\
\hline Pennsylvania State (UPM) & B & $\mathrm{L}$ & $\mathrm{M}$ & $4,779,165$ & 651 & $63,061 * * *$ \\
\hline Purdue (IPL) & $\mathrm{b}$ & & & $2,430,566$ & 260 & 35,024 \\
\hline Wisconsin (GZM) & & $\mathrm{L}$ & $\mathrm{M}$ & $7,232,850$ & 604 & 36,230 \\
\hline Total & & & & $73,235,210$ & & \\
\hline \multicolumn{7}{|c|}{$\begin{array}{l}\text { b - Basis of volume count is bibliographic } \\
\text { B - Includes branch campuses } \\
\text { G - Government documents not included in serials count } \\
\text { L - Includes Law Library } \\
\text { M - Includes Medical Library } \\
\text { * Includes professional staff, support staff, and student } \\
\text { ** Includes both undergraduate and graduate students. } \\
* * * \text { Includes all regional campuses. }\end{array}$} \\
\hline
\end{tabular}


Challenges Facing High-volume Interlibrary Loan Operations 83

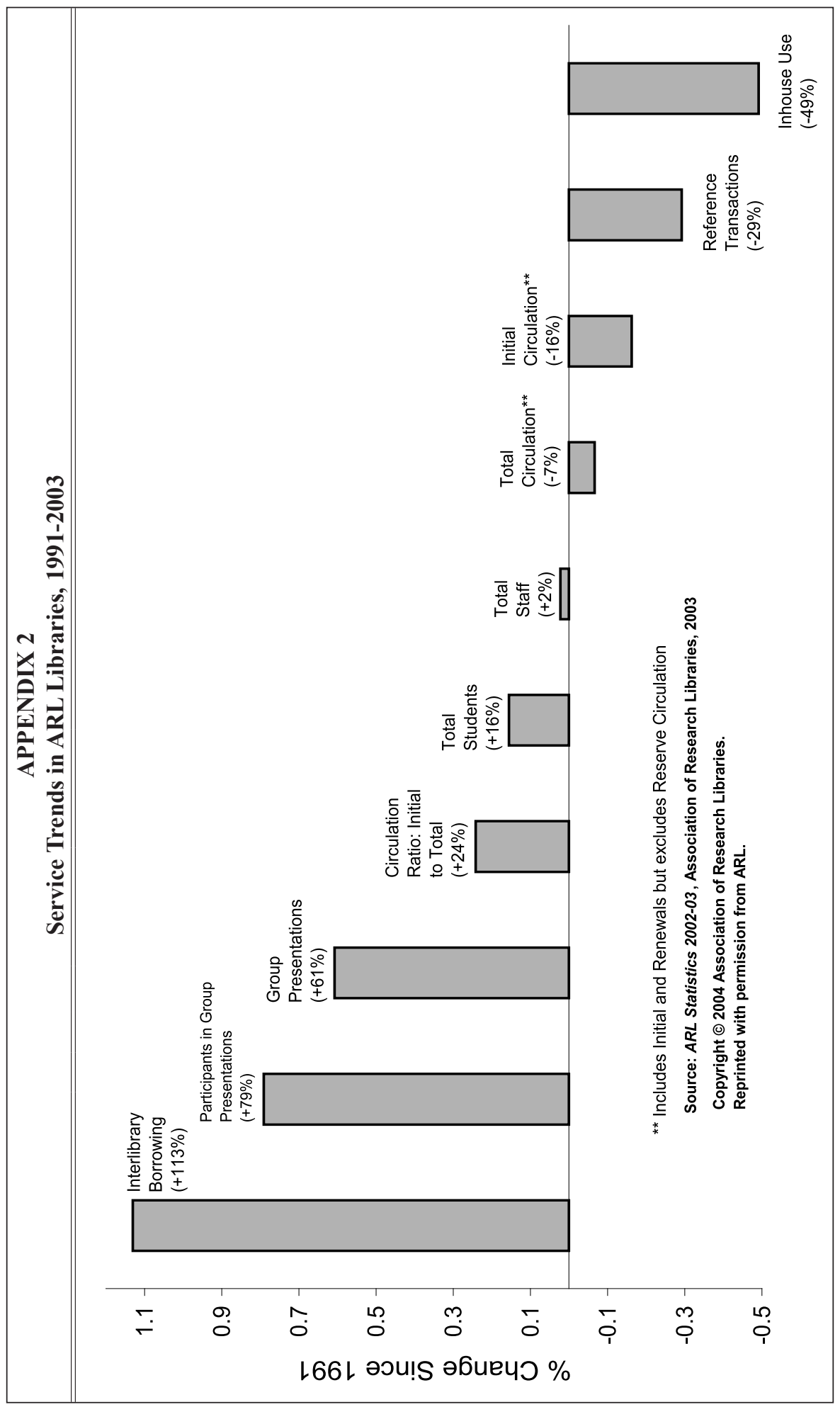




\begin{tabular}{|l|l|}
\hline \multicolumn{2}{|c|}{ APPENDIX 3 } \\
CIC ILL Directors, 2004 \\
\hline \hline Institution & Name \\
\hline University of Chicago & James Vaughan \\
\hline University of Illinois at Chicago & Robert A. Daugherty \\
\hline University of Illinois - Urbana-Champaign & Lynn Wiley \\
\hline Indiana University & Rita Rogers \\
\hline University of Iowa & Amy Fuls \\
\hline University of Michigan & Anne K. Beaubien \\
\hline Michigan State University & Denise A. Forro \\
\hline University of Minnesota & Elizabeth Ringwelski (lending) \\
\hline University of Minnesota & Cherie Weston (borrowing) \\
\hline Northwestern University & Barbara Smolow \\
\hline Ohio State University & Jennifer Kuehn \\
\hline Pennsylvania State University & Barbara Coopey \\
\hline Purdue University & Suzanne M. Ward \\
\hline University of Wisconsin-Madison & Judith L. Tuohy (borrowing) \\
\hline University of Wisconsin-Madison & Mary L. Williamson (lending) \\
\hline
\end{tabular}

